\title{
CUSTOMERS' INTENTION TO USE GREEN PRODUCTS: THE IMPACT OF GREEN BRAND DIMENSIONS AND GREEN PERCEIVED VALUE
}

\author{
Aibek Doszhanov and Zainal Ariffin Ahmad \\ College of Graduate Studies \\ Universiti Tenaga Nasional (UNITEN) \\ 43000 Kajang, Selangor, Malaysia \\ aibek_dos@yahoo.com \\ azainal@uniten.edu.my
}

\begin{abstract}
This study aimed to identify the relationships between green brand dimension (green brand awareness, green brand image, and green brand trust), green perceived value and customer's intention to use green products. Data was collected through structured survey questionnaire from 384 customers of three hypermarkets in Kuala-Lumpur. Data was analyzed based on multiple regression analysis. The results indicate that there are significant relationships between green brand awareness, green brand trust, green perceived value, and customer's intention to use green products. However, green brand image was not found to have significant relationship with customer's intention to use green products. The discussion presented suggestions for marketers and researchers interested in green branding.
\end{abstract}

Key Words: Green Brand Awareness, Green Brand Image, Green Brand Trust, Green Perceived Value, Customer's Intention, Green Products

\section{INTRODUCTION}

Society has become very aware of the catastrophic ecological greenhouse gasses resulting in global warming attributed partly to industrial manufacturing activities (Chen, 2011). Ecological concern has fast become mainstream today many businesses want to develop ecological opportunities (MolinaAzorın, 2009). In the ecological era, companies consider more in green marketing in the majority of the industries (Chen, 2010). Nevertheless, not all companies have sufficient abilities to undertake green marketing strategies. If companies want to take on green marketing initiatives, they have to apply the model of green marketing into all aspects of marketing activities routine (Ottman, 1992). Because the society is more ready to buy eco-friendly products with enough dependable information, corporations have to provide trustworthy information for their customers in order to develop their green brand and enhance green knowledge (Peattie, 1992). It is difficult for marketers to persuade their clients to buy their products without providing sufficient information to their consumers. Corporations must show more information about the green performance of their products to get their customers' trust.

Although many studies explored the different aspects of green brand (Kilbourne, 2008; Polonsky, 1994), there is a lack of empirical studies about how to increase customers' intentions to use green products among Malaysian users. Moreover, the marketplace is now practicing a renewed attention in environmentally oriented problems with a more persistent concentration on the customer market (Diamantopoulos et al., 2003). Previous studies have looked at green brand awareness (GBA), green brand trust (GBT) and green brand image (GBI) of green products (Chen, 2010). Mourad and Ahmed (2012) looked at green perceived value (GPV). However no studies have looked at all these together. Based on Chen's (2010) study on green brand dimensions to intention to use green products, one suggestion was to apply the three dimensions (GBA,GBT and GBI) and green perceived value (GPV) to intention to use green products. Green brand dimensions; green brand awareness, green 
brand trust, green brand image and green perceived value might have a relationship to intention to use green products.

The first gap in this study is lack of empirical studies on green brand awareness, green brand trust, green brand image and green perceived value to intention to use green products in the Malaysia. (Kilbourne, 2008; Polonsky, 1994). These studies have linked green brand awareness to various variables such as green perceived risk (Fryxell, 2003) and purchase decisions (Koellner, 2001), but not with intention to use green products. Previous studies have looked at green brand awareness, green brand trust, and green brand image on intention to use green products (Chen, 2010), and green perceived value to intention to use green products (Mourad and Ahmed, 2012). However, neither of them have focused on green brand dimensions and perceived value on intention to use green products. This is the literature gap and literature review for this study. Therefore, the problem being investigated in this study is whether green brand dimensions (GBA, GBT and GBI) and green perceived value (GPV) has a relationship to intention to use green products among Malaysian consumers.

\section{LITERATURE REVIEW}

\section{Intention to Use}

The Theory of Reasoned Action (TRA) has been broadly developed in comprehending consumers' decision-making processes in different contexts (Han \& Kim, 2010). According to TRA, behavioral intention is a function of two factors; namely, attitude toward subjective norm and performing the behavior (Han \& Hsu, 2010). TRA proved its applicability in explaining social behavior purposed at buying green products. The most excellent predictors of the intention to buy green products are attitudes towards the behavior perceived value. The study by Vazifehdoust (2013) indicated that the intention of customers to buy green products is defined by having a positive attitude and green perceived value toward green products. The study also has examined the impact of a variety of marketing factors and personal on the attitude toward green products of customers.

\section{Green Brand Awareness}

Green brand awareness is defined as "the ability for a buyer to recognize and to recall that a brand is environmental friendly" (Tseng, 2013, p. 98). $\mathrm{Ng}$ (2013) stated that increasing awareness amongst customers on environmental threats caused by electronic products has pushed companies to incorporate eco-friendly attributes in their products to fulfill consumers green expectations. Therefore, companies that offer environmentally sustainable products/services enhance green perceived value of their brands. However, incorporating green attributes in a product may not directly influence perceived value of a trade name. Ottman (2008) found that there is a strong positive effect and correlation of green awareness, green brand image and green trust and green brand preference. Chen (2012) indicates that awareness about products, especially green products, create positive perception about the products and decrease the perceived risk of green products. According to Chen (2012) green brand awareness is "the ability for a buyer to recognize and to recall that a brand is environmental friendly". And this study argues that that green perceived quality and green brand awareness are positively related to buying decision of customers. Moreover, according to social cognitive theory, environmental issues modify the human behavior (Zarnikau, 2003). And human behavior influences the aspects of the ecological to which they are exposed. For instance, education and awareness about green products significantly influence on buying behavior of customers (Aman, 2012; Chahal, 2010; Suki et al., 2013). Therefore, it can be hypothesized that: 
$\mathrm{H}_{1}$ : Green brand awareness has positive significant relationship with customers' intention to use green products.

\section{Green Brand Trust}

In this study, green brand trust is defined as "the readiness to be depended on only one thing based on the trust or belief resulting from its reliability, kindness, and capability about eco-friendliness" (Chen, 2010, p. 192). Trust summoned from three viewpoints - benevolence, ability and integrity-is an expectation held by one party that the word, statement or promise of a different party be able to be relied on (Rotter, 1971). Besides, trust is a level of the self-belief that another party will act as expected. Consumer trust is a primary determinant of long-term consumer behavior (Lee et al., 2011). For this reason, customer intentions to buy are affected by customer trust (Harris and Goode, 2010). Previous literature supports that buyer trust is a determinant of customer intentions to buy (Schlosser et al., 2006). Multiple studies have proved that customers purchase intentions significantly affected by customers' trust and it is a determinant of consumer purchase intentions (Lee et al., 2011; Schlosser et al., 2006). The study findings by Kang (2012) affirm that green satisfaction has positive effects on green trust and green affect. Also, the results support hypothesis in positive effects in both green brand trust and green brand affect on green brand loyalty. Hence, green trust and loyalty has positive effect on intention to buy eco-friendly products. Customer trust is a fundamental determinant of long-term consumer behavior (Lee et al., 2011). If buyers have had a trust experience with the seller, they would possess a higher level of purchase intentions. Thus, consumer trust is an antecedent of customer intentions to use (van der Heijden et al., 2003; Ercis, 2012; Mohamed, 2012; Asgharian, 2012). Based on the reviewed literatures the following hypothesis can be inferred:

$\mathrm{H}_{2}$ : Green brand trust has positive significant relationship with customers' intention to use green products.

\section{Green Brand Image}

Green brand image is defined as "as a whole range of impressions, conceptions and apprehensions towards a brand in the customers' memory which is correlated to the sustainability and eco-friendly concerns" (Chen, 2010, p. 309). Green brand image is a subset of the overall brand image. It is plausible that when a firm proclaims to deliver environmentally friendly products, the existing quality perceptions in consumer mind may positively influence to enhance a greener brand image. Cretu (2007) defines brand image as the consumer's mental visuals that illustrate a specific brand which is related to the products produced by a company. Ko (2013) indicates that the outcomes of green marketing significantly related to the creating a positive brand image for green products, and results shows that the customers intention to use green brand product, generally identity in combination with product excellence and company social responsibility views. Mourad (2012) stated the green brand image is understood to have a positive effect on the green brand choice. In other words, a company reputation is significantly affected by green brand image, and positive brand image and company's reputation increase customer's intention to use green products. Juwaheer (2012) argued that the appropriate marketing strategy to create positive brand image is the initial step toward a company's success in attracting more customers and creating loyal customers for company's products. Based on social cognitive theory, individuals act in way that is highly acceptable in the society and tend to choose the products which are more well-known. It means that the reputation and image of a brand seems a good reason of the buying activities, decisions, and behaviors of individuals (Bandura, 1989; Juwaheer, 2012; Yusof, 2012; Mayer, 2012; Namkung, 2013). Therefore, it is hypothesized: 
$\mathrm{H}_{3}$ : Green brand image has positive significant relationship with customers' intention to use green products.

\section{Green Perceived Value}

Perceived value is described as a customer's general assessment of the net benefit of a service or product based on a customer's judgment (Bolton, 1991). Past research has broadly studied perceived value because it has a positive effect on marketing performance (Sweeney et al., 1999). Because perceived value is more significant today's, corporations can increase customer purchase intention through product value (Steenkamp, 2006). A product can send message value to customers by presenting them by distinguishing the product from competitors' and other benefits (Zeithaml, 1988). Prominent product value for businesses can distinguish their products from their competitors' (Kim, 2008). Perceived value can not only be a central determinant in maintaining long-term consumer relationships, and also play a key role in affecting intentions to buy (Zhuang, 2010). Besides, perceived value is also significant in influencing consumer trust (Kim et al., 2008). Also, business that regularly increases their new eco-friendly products in the market; they allocate themselves to way in the new marketplace, to enhance their effectiveness, and to take pleasure in economical advantages more than the businesses that are not worried about ecological problems (Chang. 2008). The green value increases the awareness of social value. Keller (2011) has stated that the green perceived value is one of the most important for green users. A lot of consumers really care about their purchases, it is important for them that green products which they buy were accepted in their social surrounds. If a product execute poorly in terms of social approval, negative incident like disagreement or dissatisfaction are probably could happen (Keller, 2011; Chi, 2012; Zhuang, 2010; Ansar, 2013; Li, 2013; Dumitrescu, 2013; Mahesh, 2013; Szocs, 2012; Ng, 2013). Based on the discussion above it can be hypothesized that:

$\mathrm{H}_{4}$ : Green perceived value has positive significant relationship with customers' intention to use green products.

\section{Theoretical Framework}

The theoretical framework of this study was adapted from previous studies mainly Chen (2010) and Mourad and Ahmed, (2012). Chen (2010) conducted a study on the relationship of the green brand dimensions (GBA, GBT, GBI) to intention use green products. For this study, the researcher is expanding Chen's (2010) study to include green perceived value by Mourad and Ahmed (2012) to intention to use green products. Mourad and Ahmed (2012) focused that green perceived value significant positive relationship to intention to use green products. The underlying theory for this study was Theory of Reasoned Action as shown in Figure 1 below.

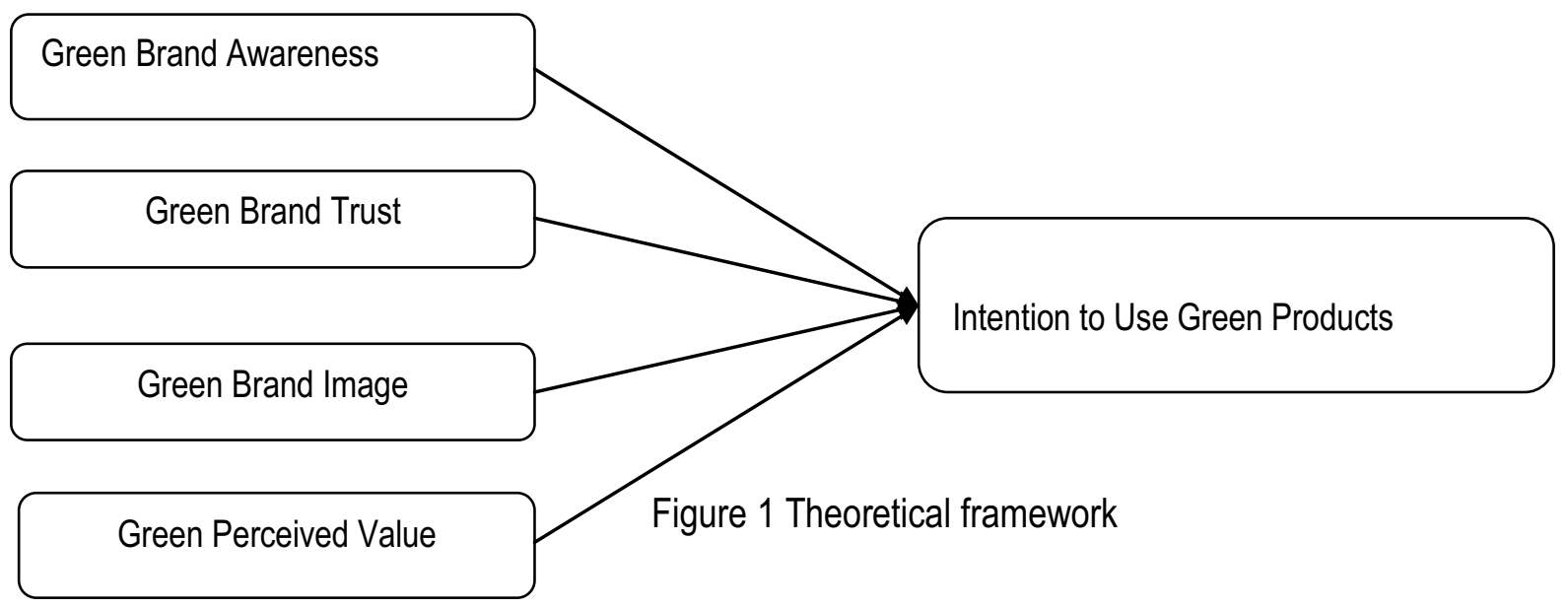




\section{METHODOLOGY}

This study is an explanatory research employing the quantitative research method to accomplish the objective of the study which is to identify the relationship between green brand awareness, green brand trust, green brand image, perceived value and customers' intention to use green products. These types of studies are appropriate to examine the significance of the correlations between investigated constructs (Creswell, 2008).

The population of this study includes all customers of hypermarkets like Carrefour, Giant, and Tesco in Kuala Lumpur. In these hypermarkets, multiple types of green products are available such as green electronic products, green packed products, grocery products and different eco-friendly products. As this study is not focused on specific types of products, population of this study consist majority of people who are customers of these hypermarkets. However, actual number of customers is unknown, because there is no way to quantify how many customers enter to these hypermarkets (Mourad and Ahmed, 2012). It would have been ideal to survey the whole population, however, the population of this study was unknown which was impossible to include entire population. Therefore, this study used convenience sampling technique and the subjects were selected because of their convenient accessibility and proximity to the researcher.

A survey questionnaire designed to collect primary data from customers to explain the relationship between variables. A total of 500 survey questionnaires were distributed among customers of three hypermarkets from $5^{\text {th }}$ of November 2013 till $5^{\text {th }}$ of December 2013. From 500 survey questionnaires, 392 questionnaires were filled up and collected. From collected survey questionnaires eight questionnaires had some un-answered questions; therefore these questionnaires were considered as incomplete data. Overall, 384 survey questionnaires were usable as relevant data for further analyses. To analyze the relationship between selected factors, multiple regression analysis was used.

\section{FINDINGS}

Demographic questions of the designed survey questionnaire of this study were asking the respondents' age, gender, level of education, occupation and level of income. The frequency and percentage of demographic distribution of 384 respondents are presented in Table 1.

Table 1

Demographic Distribution

\begin{tabular}{lcc}
\hline Items & Frequency & Percentage \\
\hline Male & Gender & \\
Female & 257 & $66.9 \%$ \\
\hline 30 or below & 127 & $33.1 \%$ \\
$31-40$ & Age & $33.1 \%$ \\
$41-50$ & 127 & $21.1 \%$ \\
Above 50 & 81 & $19.8 \%$ \\
\hline & 76 & $26.0 \%$ \\
\hline Diploma & 100 & $16.1 \%$ \\
Bachelor Degree & Level of Education & $56.2 \%$ \\
Post Graduate & 62 & $4.2 \%$ \\
Other & 216 & $23.4 \%$ \\
\hline
\end{tabular}


SHS Web of Conferences

\begin{tabular}{lcc}
\hline & Occupation & \\
\hline Employed & 66 & $17.2 \%$ \\
Self-Employed & 25 & $6.5 \%$ \\
Student & 80 & $20.8 \%$ \\
Retired & 95 & $24.7 \%$ \\
Housewife & 40 & $10.4 \%$ \\
Other & 78 & $20.3 \%$ \\
\hline & Level of Income \\
\hline Less than 2,000 & 164 & $42.7 \%$ \\
Between 2,000 and 4,000 & 134 & $34.9 \%$ \\
Between 4,000 and 6,000 & 56 & $14.6 \%$ \\
Between 6,000 and 10,000 & 5 & $1.3 \%$ \\
More than 10,000 & 25 & $6.5 \%$ \\
\hline
\end{tabular}

According to the results of factor analysis, the measurement items for the defined constructs are related to that factor and presented in Table 2(Factor $1=$ Green brand Awareness, Factor 2= Green brand image, Factor $3=$ Green brand trust, Factor $4=$ Green perceived value, Factor $5=$ Intention to use green products). Communalities for all four questions related to customer's intention to use green products are more than .70. Therefore, all four measurement items are reliable items for measuring customers' intention to use green products.

Table 2

Factor Analysis

\begin{tabular}{|c|c|c|c|c|c|}
\hline \multirow[t]{2}{*}{ Items } & \multicolumn{3}{|c|}{ Component } & \multirow[b]{2}{*}{4} & \multirow[b]{2}{*}{5} \\
\hline & 1 & 2 & 3 & & \\
\hline I am aware of the environmental efforts exerted by this brand. & .86 & .40 & 50 & 35 & 26 \\
\hline I have seen some environmental labels and slogans for this brand. & .91 & .43 & 29 & 41 & 29 \\
\hline $\begin{array}{l}\text { I recognize the meaning of the environmental slogans and symbols that my brand } \\
\text { uses its marketing campaigns. }\end{array}$ & .85 & .45 & 41 & 44 & 43 \\
\hline $\begin{array}{l}\text { I can remember some of the environmental symbols that my brand used in their } \\
\text { marketing campaigns. }\end{array}$ & .91 & 32 & 18 & 52 & 64 \\
\hline If I notice an environmental label on one brand I will prefer to use it. & .88 & 47 & 24 & 28 & 32 \\
\hline $\begin{array}{l}\text { I think brand of green products is the best benchmark in environmental } \\
\text { commitments. }\end{array}$ & .38 & 90 & 44 & 22 & 24 \\
\hline The brand's environmental reputation is handled in a professional manner. & .40 & 84 & 31 & 12 & 41 \\
\hline The brand is successful in its environmental performance. & .29 & 93 & 45 & 58 & 45 \\
\hline Brand of green products is truly about environmental promises. & 19 & 79 & 56 & 47 & 10 \\
\hline Brand of green products is well established about environmental concern. & .46 & 91 & 38 & 20 & 15 \\
\hline $\begin{array}{l}\text { I feel that green products brand's environmental commitments are generally } \\
\text { reliable. }\end{array}$ & .42 & 66 & 84 & 35 & 22 \\
\hline $\begin{array}{l}\text { I feel that green products brand's environmental performance is generally } \\
\text { dependable. }\end{array}$ & .35 & 49 & 94 & 56 & 26 \\
\hline $\begin{array}{l}\text { I feel that green products brand's environmental argument and case is generally } \\
\text { trustworthy. }\end{array}$ & .40 & 15 & 82 & 44 & 27 \\
\hline Green products brand's environmental concern meets my expectations. & .48 & 46 & 92 & 68 & 10 \\
\hline
\end{tabular}




\begin{tabular}{|c|c|c|c|c|c|}
\hline $\begin{array}{l}\text { Green products brands keep promises and commitments for environmental } \\
\text { protection. }\end{array}$ & .39 & 41 & 92 & 35 & 31 \\
\hline The product's environmental functions provide very good value for me. & .30 & 31 & 46 & 92 & 22 \\
\hline The product's environmental performance meets my expectations. & .19 & 47 & 56 & 87 & 10 \\
\hline I purchase product because it has more environmental concern than other products. & .56 & 43 & 53 & 84 & 29 \\
\hline I purchase product because it is environmental friendly. & .56 & 59 & 33 & 96 & 17 \\
\hline I purchase product because it has more environmental benefit than other products. & .67 & 11 & 29 & 94 & 32 \\
\hline $\begin{array}{l}\text { It makes sense to use green products instead of other products because of its } \\
\text { environmental commitments }\end{array}$ & .58 & 65 & 26 & 24 & 94 \\
\hline $\begin{array}{l}\text { Even if another product has the same features, I would prefer to use products with } \\
\text { environmental commitments }\end{array}$ & .48 & 42 & 13 & 20 & 93 \\
\hline $\begin{array}{l}\text { Even if there is another product as good quality as green products, I prefer to use } \\
\text { greed one }\end{array}$ & .53 & 27 & 19 & 29 & 91 \\
\hline $\begin{array}{l}\text { If there is not environmental concern in other products it seems smarter to use } \\
\text { green products }\end{array}$ & .56 & 28 & 32 & 17 & 90 \\
\hline Eigenvalue & 18.12 & 1.74 & 1.55 & 1.32 & 1.23 \\
\hline$\%$ Variance & 55.52 & 7.56 & 6.44 & 5.73 & 5.34 \\
\hline $\begin{array}{l}\text { KMO measure of sample adequacy }(0.87 \text { ) } \\
\text { Bartlett's Test of Sphericity (Approx. Chi-Square }=987.67, p<0.01 \text { ) }\end{array}$ & & & & & \\
\hline
\end{tabular}

The results of descriptive analysis and reliability test are presented in Table 3. Based on Vogt (2007), the Cronbach's Alpha value more than .70 for designed questions indicate that the measurement items are a good items to measure a construct. The means for the variables range from 3.12 to 3.67 .

Table 3

Descriptive Analysis and Reliability

\begin{tabular}{|l|c|c|c|c|}
\hline \multicolumn{1}{|c|}{ Variables } & Mean & S.D. & No. of Items & Cronbach's Alpha \\
\hline Customers' Intention to Use Green Products & 3.55 & 1.13 & 4 & .94 \\
\hline Green Brand Awareness & 3.67 & .96 & 5 & .92 \\
\hline Green Brand Trust & 3.48 & 1.10 & 5 & .91 \\
\hline Green Brand Image & 3.48 & 1.06 & 5 & .93 \\
\hline Perceived Value & 3.12 & 1.32 & 5 & .95 \\
\hline
\end{tabular}

The Pearson Correlation value shows the correlation between variables and should be between -1 and 1 . The amount close to 1 shows high correlation, and negative amount shows negative correlation. Based on information based on Table 4, there is high correlation between the independent variables and customer's intention to use green products as all Pearson values are more than .90. 
SHS Web of Conferences

Table 4

Correlations

\begin{tabular}{l|ccccc} 
& $\begin{array}{c}\text { Intention to Use } \\
\text { Green Products }\end{array}$ & $\begin{array}{c}\text { Green Brand } \\
\text { Awareness }\end{array}$ & $\begin{array}{c}\text { Green Brand } \\
\text { Trust }\end{array}$ & $\begin{array}{c}\text { Green Brand } \\
\text { Image }\end{array}$ & $\begin{array}{c}\text { Green } \\
\text { Perceived Value }\end{array}$ \\
\hline Intention to Use & 1.00 & & & & \\
Green Products & .97 & 1.00 & & & \\
Green Brand Awareness & .95 & .90 & 1.00 & & \\
Green Brand Trust & .94 & .93 & .92 & 1.00 & \\
Green Brand Image & .92 & .87 & .89 & .86 & 1.00 \\
Green Perceived Value & .89 & & \\
\hline
\end{tabular}

\section{FINDINGS}

Table 5 represents the model summary for the analysis done based on the model presented in this study. From the model summary table, customers' intention to buy green products can be explained by green brand awareness, green brand trust, green brand image, and green perceived value. With the Adjusted $\mathrm{R}^{2}=.97$, therefore, it can be argued that 97 percent of variations in customers' intention to use green products can be explained by green brand awareness, green brand trust, green brand image, and green perceived value.

Table 5

Model Summary

\begin{tabular}{|c|c|c|c|c|c|c|c|c|c|c|}
\hline \multirow[b]{2}{*}{ Model } & \multirow[b]{2}{*}{$\mathrm{R}$} & \multirow[b]{2}{*}{$\begin{array}{l}\mathrm{R} \\
\text { Square }\end{array}$} & \multirow[b]{2}{*}{$\begin{array}{l}\text { Adjusted } \\
\text { Square }\end{array}$} & \multirow{2}{*}{$\mathrm{R} \mid \begin{array}{l}\text { Std. Error of } \\
\text { the } \\
\text { Estimate }\end{array}$} & \multicolumn{5}{|c|}{ Change Statistics } & \multirow[b]{2}{*}{$\begin{array}{l}\mathrm{F} \text { Durbin- } \\
\text { Watson }\end{array}$} \\
\hline & & & & & 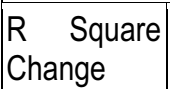 & \begin{tabular}{|l} 
F \\
Change
\end{tabular} & df1 & df2 & \begin{tabular}{|l|} 
Sig. \\
Change
\end{tabular} & \\
\hline 1 & $.99 \mathrm{a}$ & .970 & .97 & .19 & .97 & 3087.69 & 4 & 379 & .000 & 2.593 \\
\hline
\end{tabular}

a. Predictors: (Constant), Green Perceived Value, Green Brand Image, Green Brand Trust, Green Brand Awareness

b. Dependent Variable: Intention to Use GreenProducts

The results of F-test clarify how much the model presented in this study is an acceptable model to describe variations in customers' intention to use green products. Table 6 shows the P-value for ANOVA is 0.00 less than .05 indicating that the model presented in this study is an appropriate model.

Table 6

ANOVA

\begin{tabular}{|ll|l|l|l|l|l|}
\hline Model & & Sum of Squares & Df & Mean Square & F & Sig. \\
\hline 1 & Regression & 472.00 & 4 & 118.00 & $3.08 \mathrm{E} 3$ & $.000^{\mathrm{a}}$ \\
& Residual & 14.48 & 379 & .04 & & \\
& Total & 486.48 & 383 & & & \\
\hline
\end{tabular}

a. Predictors: (Constant), Green Perceived Value, Green Brand Image, Green Brand Trust, Green Brand Awareness

b. Dependent Variable: Intention to Use Green Products

Table 7 shows the P-value is .00 for the relationship between green brand awareness and customers' intention to use green products. Therefore, it can be inferred that green brand awareness 
has a significant relationship with customers' intention to use green products. And the beta value for the relationship between green brand awareness and customers' intention to use green products is .60 . The amount indicates that the relationship between green brand awareness and customers' intention to use green products is positive. Consequently, $\mathrm{H}_{1}$ is accepted.Similarly, the P-value for the relationship between green brand trust and customers' intention to use green products is also .00 . Therefore, it can be argued that green brand trust has significant relationship with customers' intention to use green products. Moreover, the beta value for this relationship is .30. Hence, $\mathrm{H}_{2}$ is accepted.

Table 7

Multiple Regression Results

\begin{tabular}{|l|c|c|c|c|c|}
\hline \multirow{2}{*}{ Model } & \multicolumn{2}{|c|}{ Unstandardized Coefficients } & \multicolumn{2}{c|}{$\begin{array}{c}\text { Standardized } \\
\text { Coefficients }\end{array}$} & \\
\cline { 2 - 7 } & $\mathrm{B}$ & Std. Error & Beta & $\mathrm{t}$ & Sig. \\
\hline 1 (Constant) & -.31 & .05 & & -6.86 & .000 \\
Green Brand Awareness & .60 & .03 & .51 & 18.33 & .000 \\
Green Brand Trust & .31 & .03 & .30 & 11.13 & .000 \\
Green Brand Image & .05 & .03 & .05 & 1.55 & .122 \\
Green Perceived Value & .14 & .02 & .16 & 7.59 & .000 \\
\hline
\end{tabular}

a. Dependent Variable: Intention to Use Green Products

Based on the results, Hypothesis 3 is rejected because the P-value is .12 for the relationship between green brand image and customers' intention to use green products and the beta value is .05.Lastly, there is a significant and positive relationship between perceived value and customer's intention to use green products(P-value $=.00)$. The Beta value is .14 , hence, $\mathrm{H}_{4}$ is accepted. Based on results of multiple regression analysis the following formula for the linear regression model of this study can be explored:

\section{Customers' intention to use green products $=.51$ * Green Brand Awareness +.30 * Green Brand Trust + .05* Green Brand Image + .16 * Green Perceived Value}

\section{DISCUSSION}

Based on the findings of this study all defined constructs have positive relationship with customers' intention to use green products, except green brand image. The relationships between green brand awareness, green brand trust, green perceived value and customers' intention to use green products were significant. Consequently, this study explored that green brand awareness, green brand trust, and green perceived value have significant positive relationship with customer's intention to used green products.

The findings of this study support the findings of Mourad and Ahmed, (2012), Cheah and Phau, (2011), Chen and Chang, (2012). Researches indicate that awareness about products, especially green products, create positive perception about the products and decrease the perceived risk of green products. Moreover, according to social cognitive theory, environmental issues modify the humans' behavior. And human's behavior influences the aspects of the ecological to which they are exposed.

The results show that the relationship between green brand trust and customers' intention to use green products is significant positive relationship. The findings support the findings of Lee et al., (2011), Schlosser et al., (2006), Harris and Goode (2010) and Schlosser et al., (2006) that customers purchase intentions significantly affected by customers' trust and it is a determinant of consumer 
purchase intentions. These findings indicate that customer trust is a fundamental determinant of consumer behavior, and if buyers have had a trust experience with the seller, they would possess a higher level of purchase intentions. Therefore, organization should strategies for organization to create trust about their products, in order to encourage customers to buy them.

However, the findings of this research reveal that the relationship between green brand image and customers' intention to use green products is not significant. The results of this study differ from previous studies (Juwaheer, 2012; Mourad and Ahmed, 2012; Hartmann, 2005; and Mourad, 2012) which found significant positive relationship between green brand image and customer's intention to use green products. This could be due to the lack of clear green brand image such as environmental friendly productsas this study focused on green brand in general.

The findings of the research explored that there is significant positive relationship between green perceived value and customer's intention to use green products. The findings support the findings of Cheah and Phau (2011) Chen and Chang (2012), Steenkamp and Geyskens (2006) and Keller (2011). Green products have great value both for individuals and for environment, therefore, there is a good opportunity for organizations highlight the value of their products to enhance consumers' intention to use environmental friendly products. Moreover, according to the Theory of Reasoned Action, if a customer feels that there are desire outcomes and values for choosing a products or taking an action, he or she has incentive and motivation to engage in those actions or select those products (Ajzen and Fishbein, 1975, 1980; Bandura, 1977). And this study and previous studies indicate that perceived value for customers' plays fundamental role to use green products. The social impact of this study supports the importance of perceived value held by the community represented by the customers, and this can affect public policy on green products in Malaysia.

There were some limitations for this study. First, this study did not focus on specific product or specific brand. As green products are very diverse, it was hard for the researcher to investigate the relationship between brands dimensions and customers intention to use specific green branded product. This study included all green products in hypermarkets. Future scholars could use the theoretical framework provided in this study to analyze it for specific brand and product. This study conducted on the customers of hypermarkets. Future studies should focus on other markets to identify the relationships between defined variables.

Secondly, due to lack of time the researcher was not able to study more variables and as highlighted in the literature review as well as moderators and mediators. There are more brand dimensions, or other factor based on Social Cognitive Theory and Theory of Reasoned Action which can influence customers' intention to use green products. As this research found that green brand image did not have significant relationship with customer's intention to use green products, future study could explore the effects of green brand image in different circumstances.

This study focused on Theory of Reasoned Action to identify the relationship between brand dimensions and perceived value and customers' intention to use green products. The findings of this study provide a good evidence for scholars to explore the effects of brand awareness, brand trust, and perceived value of green products on customers buying behavior. And, this study explored the implication of Theory of Reasoned Action and Social Cognitive Theory in green marketing which provide opportunities to further studies to support for these theories.

\section{CONCLUSION}

In conclusion, the findings of this research indicate that there are significant relationships between green brand awareness, green brand trust, green perceived value and customers' intention to 
use green products. The findings of this study bear implications to companies to improve the awareness of customers about their green products, create green brand trust among customers, and enhance green perceived value for customers to increase their intention to use green products.

\section{REFERENCES}

Ali, A. (2012). Environment friendly products: factors that influence the green purchase intentions of Pakistani consumers. Pakistan Journal Of Engineering And Technological Science. Vol. 2 (1), pp. 84-117.

Alwitt, L. F. (1996). Predicting purchase intentions for an environmentally sensitive product. Journal Of Consumer Psyhology. Vol. 5 (1), pp. 49-64.

Aman, A. L. (2012). The influence of environmental knowledge and concern on green purchase intention the role of attitude as a mediating variable. British Journal of Arts and Social Sciences. Vol. 7 (3), pp. 2046-9578.

Ansar, N. (2013). Impact of Green Marketing on Consumer Purchase Intention. Mediterranean .Journal of Social Sciences. Vol. 4 (11), pp. 23-45.

Asgharian, R. (2012). Green product quality, green customer satisfaction, and green customer loyalty. International Journal of Research in Management \& Technology. Vol. 2 (5), pp. 2249-9563.

Azizan, S. A. (2013). Consumers' intention to purchase green product: insights from malaysia.World Applied Sciences Journal, Vol. 22 (8), pp. 1129-1134.

Azorı'n, J. F. (2009). Green management and financial performance: a literature review. Management Decision. Vol. 47 (7), pp. 1080-1100.

Ballester, E. D. (2005). Does brand trust matter to brand equity. Journal of Product \& Brand Management.Vol. 14 (3), pp. 187-196.

Bamberg, S. (2003). How does environmental concern influence specific environmentally related behaviors? A new answer to an old question. Journal of Environmental Psychology. Vol. 23, pp. 21-32.

Bandura, A. (1977). Self-efficacy; Toward a Unifying Theory of Behavior Change. Psychological Review. Vol. 22 (2), pp. 191-215.

Bandura, A. (2001). Social Cognitive Theory: An Agentic Perspective. Annual Review of Psychology. Vol. 32 (1), pp. 33-56.

Bergh, B. v. (2010). Consumer choices: Going green to be seen. Management Knowledge. Vol. 8 (3), pp.33-87.

Bolton, R. N. (2012). A multi-stage model of customer' assessments of service quality and value. Marketing Journal. Vol.4, pp. 55-99. 
Brown, D. (2008). It is good to be green Environmentally friendly credentials are influencing business outsourcing decisions. Strategic Outsourcing: An International Journal. Vol. 1 (1), pp. 87-95.

Chahal, H. (2012). Significant components of service brand equity in healthcare sector. International Journal of Health Care. Vol. 25 (4), pp. 343-362.

Chan, Y. R. (2000). Antecedents of green purchases: a survey in China .Journal of Consumer Marketing. Vol. 17 (4), pp. 338-357.

Chang, D.-S. (2008). The effects of sustainable development on firms' financial performance - an empirical approach.Sustainable Development.Vol. 389-401 (2), pp. 365-380.

Chatterjee, P. (2009). Green brand extension strategy and online communities. Journal of Systems and Information.Vol. 11 (4), pp. 367-384.

Chen, Y. S. (2012). Enhance green purchase intentions. The roles of green perceived value, green perceived risk, and green trust. Management Decision. Vol. 50 (3), pp. 502-520.

Chen, Y. S. (2010). The drivers of green brand equity: green brand image, green satisfaction, and green trust.Journal of Business Ethics.Vol. 93, pp. 307-319.

Chen, Y. S. (2012). The influences of green perceived quality and green brand awareness on green brand equity: the mediation effect of green perceived risk. Technology Management for Emerging Technologies.Vol. 45 (1), pp. 23-43.

Chen, Y. S. (2013). Towards green loyalty: driving from green perceived value, green satisfaction, and green trust. Sustainable Development. Vol. 23 (2), pp.294-308.

Chi, H. (2013). The Influences of Perceived Value on Consumer Purchase Intention: The Moderating Effect of Advertising Endorser. Journal of Marketing.Vol. 23 (3), pp. 456-543.

Creswell, J. W. (2008). Methodological issues in conducting mixed methods research designs. Advances in Mixed Methods Research.pp. 66-83.

Cretu, E. A. (2007). The influence of brand image and company reputation where manufacturers market to small firms: A customer value perspective. Industrial Marketing Management. Vol. 36, pp. $230-240$.

David. (2008). A Closer Look At "Green" Products. Retrieved November 3, 2013, from http://www.cbsnews.com/news/a-closer-look-at-green-products/

Desan, N. J. (2009). The Green Market - Opportunities, Competencies, Complexities. Retrieved October 12, 2013, from http://www.standardsusers.org/mysr/index.php?option=com_content\& view=article\&id=458:the-green-market-opportunities-competencies-complexities\&catid=63: papers\&ltemid $=81$

Diamantopoulos, A. (2003). Can socio-demographics still play a role in profiling green consumers? A review of the evidence and an empirical investigation. Journal of Business Research. Vol. 56 (3), pp. 465- 480. 
D'Souza, C. (2006). An empirical study on the influence of environmental labels on consumers. Corporate Communications: An International Journal. Vol. 11 (2), pp. 162-173.

Dumitrescu, C. (2013). Perceived value of pasta in Greece and Romania. British Food Journal. Vol. 115 (10), pp. 1518-1536.

Ercis, A. (2012). The Effect of Brand Satisfaction, Trust and Brand Commitment on Loyalty and Repurchase Intentions.Procedia-Social and Behavioral Sciences. Vol. 58 (3), pp.1395-1404.

Field, A. (2005). Factor analysis using SPSS.

Flavia'n, C. (2005). The influence of corporate image on consumer trust $A$ comparative analysis in traditional versus internet banking. Internet Research. Vol. 15 (4), pp. 447-470.

Fryxell, G. E. (2003). The Influence of Environmental Knowledge and Values on Managerial Behaviours on Behalf of the Environment: An Empirical Examination of Managers in China. Journal of Business Ethics. Vol. 46 (1), pp. 45-69.

Gabriano, E. (1999). The different role of satisfaction, trust and commitment in customer relationship. Journal of Marketing.Vol. 63 (2), pp.70.

Ghazali, R. (2011). 'No plastic bag day campaign' a success, S'gor mulling additional day. Retrieved November 23, 2013, from http://archive.freemalaysiatoday.com/fmt-english/news/general/ 12737-no-plastic-bag-day-campaign-a-success-sgor-mulling-additional-day

Grimmer, M. (2013). Company environmental performance and consumer purchase intentions. Journal of Business Research. Vol. 66 (5), pp. 1945-1953.

Grob, A. (1995). A structural model of enviromental attitude and behavior.Journal of Environmental Psychology. Vol. 15, pp. 209-220.

Grove, S. J. (1996). Going green in the service sector Social responsibility issues, implications and implementation. European Journal of Marketing. Vol. 30 (5), pp. 56-66.

Han, H. (2010). Application of the Theory of Planned Behavior to green hotel choice: Testing the effect of environmental friendly activities. Tourism Management. Vol. 24 (1), pp.325-334.

Harris, L. C. (2010). Online servicescapes, trust, and purchase intentions. Journal of Services Marketing.Vol. 24 (3), pp. 230-243.

Hartmann, P. (2005). Green branding effects on attitude: functional versus emotional positioning strategies. Marketing Intelligence \& Planning. Vol. 23, pp. 9-29.

Hartmann, P. (2006). Green value added. Marketing Intelligence \& Planning. Vol. 24 (7), pp. 673-680.

Hoyer, W. D. (1990). Effects of brand awareness on choice for a common, repeat-purchase product. Journal of Consumer Research. Vol. 17 (1), pp. 53-87.

Jain, S. K. (2006). Role of Socio-Demographics in Segmenting and Profiling Green Consumers. Journal of International Consumer Marketing. Vol. 18 (03), pp. 46-54. 
Juwaheer, T. D. (2012). Analysing the impact of green marketing strategies on consumer purchasing patterns in Mauritius. World Journal of Entrepreneurship, Management and Sustainable Development. Vol. 8(1), pp. 36-59.

Kaiser, F. G. (1999). Environmental attitude andecological behavior.Journal of Environmental Psychology. Vol. 19 (2), pp. 1-19.

Kalafatis, S. P. (1999). Green marketing and Ajzen's theory of planned behaviour: a cross-market examination. Journal of Consumer Marketing.Vol. 16 (5), pp. 441-460.

Kang, S. (2012). Investigating the antecedents of green brand equity: a sustainable development perspective.Corporate Social Responsibility and Environmental Management.Vol. 19, pp. 306316.

Kim, C. (2008). An empirical study on the integrated framework of e-crm in online shopping: evaluating the relationships among perceived value, satisfaction, and trust based on customers' perspectives. Journal of Electronic Commerce in Organizations. Vol. 6 (3), pp. 1-19.

Ko, E. (2013). Green marketing' functions in building corporate image in the retail setting. Journal of Business Research. 66, pp.1709-1715.

Koellner, E. C. (2009). Study of Green Behavior with a Focus on Mexican Individuals.iBusiness. 10 (1), pp.124-131.

Koller, M. (2012). Consumer Loyalty: A "Green" Perspective. Psychology \& Marketing. Vol. 28 (11), pp.1154-1176.

Kotler, P. (2012). Marketing Management(14 ed.). US: Pearson.

Kwun, D. J.-W. (2007). Consumers' evaluation of brand portfolios. Hospitality Management. Vol. 26, pp.81-97.

Lai, C.-C. (2003). Environmental Regulations and Social Norms. International Tax and Public Finance. Vol. 10, pp.63-75.

Lantieri, T. (2009). Brand trust in an age without trust: expert opinions. Journal of Consumer Marketing. Vol. 26 (2), pp.78-86.

Lee, J. (2011). The different effects of online consumer reviews on consumers' purchase intentions depending on trust in online shopping malls An advertising perspective. Internet Research. Vol. $21(1)$, pp. 187-206.

Li, J.-X. (2013). The Effect of Environmental Awareness on Consumers' Green Purchasing: Mediating Role of Green Perceived Value. Verlag Berlin Heidelberg. Vol. 12 (1), pp. 43-59.

Mahesh, N. (2013). Consumers percived value, attitude and purchase intention of green products. Management Journal. Vol. 12 (1), pp. 33-44. 
Mardaneh, H. R. (2012). Consumer Acceptance Models for Green Product in Iran. International Journal of Innovative Ideas. Vol. 12 (3), pp. 1-5.

Mayer, R. (2012). Passenger perceptions of the green image associated with airlines. Journal of Transport Geography. Vol. 22, pp.179-186.

Mohamed, R. N. (2012). Cultural Uncertainty on Brand Trust of Fast Food Industry in Malaysia. Procedia - Social and Behavioral Sciences. Vol. 42, pp. $399-412$.

Mourad, M. (2012). Perception of green brand in an emerging innovative market. European Journal of Innovation. Vol. 15 (4), pp. 514-537.

Namkunga, Y. (2013). Effects of restaurant green practices on brand equity formation: Do green practices really matter? International Journal of Hospitality Management. Vol. 33, pp. 85-95.

Ng, P. F. (2013). Antecedents of Green Brand Equity: An Integrated Approach. Science+Business Media Dordrecht. Vol. 12 (2), pp. 13-43.

Nsairi, Z. B. (2012). Managing browsing experience in retail stores through perceived value: implications for retailers. International Journal of Retail \& Distribution Management. Vol. 40 (9), pp. 676-698.

Ottman, J. A. (2008). The five simple rules of green marketing. Design Management Review. Vol. 8 (2), pp. 434-478.

Polonsky, M. J. (1994). An introduction to green marketing.Electronic Green Journal. Vol. 12 (5), pp.1273-1298.

Prakash, A. (2002). Green marketing, public policy and managerial strategies.Business Strategy and the Environment. Vol.11, pp.285-297.

Rahbar, E. (2011). Investigation of green marketing tools' effect on consumers' purchase behavior.Emerald Group Publishing Limited. Vol. 12 (2), pp. 73-83.

Raska, D. (2012). When is going green good for company image? Management Research Review. Vol. 35 (3), pp.326-347.

Rios, F. J. (2006). Improving attitudes toward brands with environmental associations: an experimental approach. Journal of Consumer Marketing. Vol. 23 (1), pp. 26-33.

Roberts, J. A. (1997). Exploring the subtle relationships between environmental concern and ecologically conscious consumer behavior. Journal of Business Research. Vol. 40, pp. 79-89.

Rotter, J. B. (1978). Generalized expectancies for problem solving and psychotherapy. Cognitive Therapy and Research. Vol. 2 (1), pp. 1-10.

Sandi, F. J. (2012). Green is the new black - consumer and green products. Marketing Journal. Vol. 4 (4), pp. 98-109. 
Schlosser, A. E. (2006). Converting web site visitors into buyers: how web site investment increases consumer trusting beliefs and online purchase intentions. Journal of Marketing. Vol. 70, pp. 133-148.

Sheppard, B. H. (1988). The theory of reasoned action: a meta-analysis of past research with recommendations for modifications and future research. The Journal of Consumer Research. Vol.15 (3), pp. 325-343.

Snoj, B. (2004). The relationships among perceived quality, perceived risk and perceived product value. Journal of Product \& Brand Management. Vol. 13 (3), pp.156-167.

Steenkamp, J.-B. E. (2006). How country characteristics affect the perceived value of web sites. Journal of Marketing. Vol. 70, pp. 136-150.

Suki, N. M. (2013). Green awareness effects on consumers purchasing decision: some insights from Malaysia. IJAPS. Vol. 9 (2), pp. 33-54.

Sweeney, J. C. (1999). The Role of Perceived Risk in the Quality-Value Relationship: A Study in a Retail Environment. Journal of Retailing. Vol. 75 (1), pp. 77-105.

Szocs, C. R. (2011). Green marketing: analysis and classification. Journal of Consumer Research. Vol. 34 (1), pp. 256-263.

Tseng, S.-C. (2013). A framework identifying the gaps between customers' expectations and their perceptions in green products. Journal of Cleaner Production. Vol. 59, pp. 174-84.

Vazifehdousta, H. (2013). Purchasing green to become greener: Factors influence consumers' green purchasing behavior. Management Science Letters. Vol. 3, pp. 2489-2500.

Veisten, K. (2007). Willingness to pay for eco-labelled wood furniture: Choice-based conjoint analysis versus open-ended contingent valuation. Journal of Forest Economics. Vol. 13 (2), pp.29-48.

Vogt, W. P. (2007). Quantitative research methods for professionals. US: Pearson/Allyn and Bacon .

Woodruff, R. B. (1997). Customer Value: The Next Source for Competitive Advantage. Journal of the Academy of Marketing Science. Vol. 25 (2), pp.139-153.

Yusof, J. M. (2012). The Effects of Green Image of Retailers on Shopping Value and Store Loyalty. Procedia - Social and Behavioral Sciences. Vol. 50, pp. $710-721$.

Zanoli, R. (2002). Consumer motivations in the purchase of organic food. A means-end approach. British Food Journal. Vol. 104 (8), pp. 643-653.

Zarnikau, J. (2003). Consumer demand for 'green power' and energy efficiency.Energy Policy. Vol. 31, pp. 1661-1672.

Zhuang, W. (1997). The impact of perceived value on behavior intention: an empirical study. Journal of the Academy of Marketing Science. Vol. 4 (3), pp.34-54. 